and communicative-speech components. The formation of the PTC is determined by the level of development of its structural components. The three-level analysis of each component of PTC structure is proposed. The objectivity of the overall assessment is ensure the estimation combination of its level. Criteria PTC formation is accord to its structure which is presented by theoretical (gnosological), personality (motivational) and practical (communicative) component. The decisive significance of the subject-cognitive component is emphasized, it is manifests in the development and improvement of the active special terms vocabulary of future specialist and directly determines the theoretical (cognitive) activity and realization of reflexive and practical activity by specialist.

The characteristic of low (primary), medium (sufficient) and high (competent) levels of PTC formation is given. The three-dimensional matrix model of determination the level of formation the professional and terminology competence of future specialist is reviewed. The main tasks of the empirical definition of forming conditions of the components PTC are formulated. The main groups of methods for studying the formation level of a separate PTC component is singled out.

Key words: professional and terminological competence, criterion, indicator, level, matrix model, future teacher.

УДК 159.9:37.013

DOI https://doi.org/10.31392/2311-5491/2019-69.41

Підлипняк І. Ю., Дука Т. М.

\title{
ПРОФЕСІЙНЕ ВИГОРАННЯ ПЕДАГОГІВ: ПРОФІЛАКТИКА ТА ПОДОЛАННЯ
}

Стаття присвячена результатам порівняльного аналізу термінологічного апарату, щзо використовується для позначення феномена «професійне вигорання». Синдром «професійного вигорання» розглядається психологами як один із проявів стресу, з яким стикається людина у власній професійній діяльності. Цей термін - загальна назва наслідків тривалого робочого стресу й певних видів професійної кризи. Сучасними науковцями з 'ясовано, щчо представники професій, пов'язаних із взаємодією з людьми, зокрема педагоги, у зв 'язку з великою емоційною напруженістю, нестандартністю педагогічних ситуацій, відповідальністю і складністю схильні до розвитку синдрому «професійного вигорання». Педагог як суб'єкт освітнього проиесу здійснює вплив на особистість через призму сформованості власної актуальноиілісної сфери, саме тому, якщо він схильний до емоиійного вигорання, він потребує допомоги.

Визначено чинники, причини й симптоми виникнення цъього явщща. Окреслено основні напрями профілактики професійного вигорання фахівиів педагогічної сфери. Акцентовано на необхідності дослідження профілактичних методів і технологій запобігання професійному вигоранню.

У разі появи й розвитку ознак емоційного вигорання необхідно звернути увагу на покращення умов праці (організаційний рівень), характер взаємин у колективі (міжособистісний характер), особистісні реакиії та захворюваність (індивідуальний рівень). Суттєва роль у боротьбі з синдромом емочійного вигорання відводиться самій людині. Для запобігання синдрому «професійного вигорання» необхідно дотримуватися рекомендованих принципів власної поведінки та професійної діяльності: планування й нормування педагогічної діяльності, обов 'язковий відпочинок, розваги та посильні й приємні фізичні навантаження, психологічне розвантаження, уникання нездорової конкуренції й терпіння.

Ключові слова: педагог, професійне вигорання, емоційне вигорання, профілактика синдрому професійного вигорання.

Професія педагогів є однією серед більшості соціально значущих, тому що їхня професійна діяльність пов'язана з формуванням суспільної свідомості, передачі культурного надбання та потреб людей. Сучасна освітня система вимагає від особистості педагога швидкого реагування на щоденні події, точності його дій $і$ належного рівня сформованості його емоційної сфери. Сучасними науковцями з'ясовано, що представники професій, пов'язаних із взаємодією з людьми, зокрема педагоги, у зв'язку з великою емоційною напруженістю, нестандартністю педагогічних ситуацій, відповідальністю та складністю схильні до розвитку синдрому «професійного вигорання». Педагог як суб'єкт освітнього процесу здійснює вплив на особистість через призму сформованості власної актуально-цілісної сфери, саме тому, якщо він схильний до емоційного вигорання, він потребує допомоги.

Питання професійного вигорання відображено в працях зарубіжних і вітчизняних учених, які проаналізували структуру цього синдрому (Л. Карамушка, С. Максименко); визначили методи його діагностики (В. Бойко, Н. Водоп’янова); дослідили синдром «професійного вигорання» в учителів (Т. Зайчикова, О. Ковальчук, Г. Федосова, О. Філатова, О. Філь); розробили рекомендації $з$ подолання стресів у педагогічній діяльності (В. Калошин); визначили гендерні аспекти впливу на синдром «професійного вигорання» в професійній кар'єрі працівників освітніх організацій (Т. Зайчикова, С. Максименко); з’ясували вплив емоційного вигорання на професійну поведінку (К. Маслач, С. Джексон).

Феномен «професійне вигорання» досить грунтовно висвітлений у науковій літературі, однак сьогодні мало звертається уваги на ефективні психолого-педагогічні технології, спрямовані на профілактику виникнення цього явища та зниження ризику формування й появи професійної кризи загалом.

Варто зазначити, що професія педагога в силу своєї специфіки є стресогенною, оскільки передбачає залученість у довготривалий емоційно складний процес спілкування з особами різного віку, соціального статусу. 
Нині, за результатами вітчизняних і зарубіжних науковців, з'ясовано, що педагогічна діяльність є стресогенною, тому потребує значних резервів самовладання та саморегуляції. У результаті емоційного напруження, пов’язаного зі здійсненням ним професійної діяльності, з'являється зниження стійкості психічних функцій i, як наслідок, зниження працездатності.

Задля розуміння необхідності аналізу позитивних заходів профілактики професійного вигорання вважаємо за доцільне звернутися до поглядів науковців щодо визначення дефініцій «професійне вигорання», «емоційне вигорання» й окреслення чинників, що призводять до професійного вигорання.

На думку Д. Грінберга, професійне вигорання - це несприятлива реакція особистості на стрес, який вона отримала в процесі здійснення професійної діяльності, що містить психофізіологічні та поведінкові компоненти [4].

Феномен «професійне вигорання» І. Олійник визначає як деструктивні зміни особистості, що виникають, розвиваються та проявляються в процесі її професіоналізації як комплекс негативних симптомів, які мають стадіальний характер і виявляються в емоційному виснаженні, деперсоналізації й редукції професійних досягнень і призводять до зниження ефективності професійної діяльності й порушення суб'єкт-суб'єктної взаємодії [8].

Науковець О. Рукавішніков одним зі складників професійного вигорання розглядає «синдром емоційного вигорання» як негативне психологічне явище, що виявляється через психоемоційне виснаження, розвиток дисфункціональних професійних установок і зниження професійної мотивації [11].

Феномен «емоційне вигорання» В. Бойко визначає як вироблений особистістю механізм психологічного захисту у формі повного або часткового виключення емоцій (зниження їх енергетики) у відповідь на психотравмувальні впливи. Вигорання, на думку автора, - це набутий стереотип емоційної, найчастіше професійної, поведінки, зокрема функціональний стереотип, що дає особистості змогу дозувати та економно витрачати енергетичні ресурси [5].

Цінними в контексті дослідження виявилися погляди В. Орел, який, здійснивши аналіз та узагальнення наукових поглядів щодо трактування поняття «вигорання» [9], акцентуючи на індивідуальних та організаційних чинниках виникнення цього явища, визначає його як стан фізичного, емоційного й розумового виснаження, що виявляється в професіях соціальної сфери [7].

Аналіз визначень поняття «професійне вигорання» дав змогу виявити, що більшість авторів під цим конструктом розуміють професійний феномен, що складається з комплексу негативних (деструктивних) симптомів і містить три компоненти: емоційне виснаження, деперсоналізацію й редукцію професійних досягнень.

Проте професійна діяльність педагога передбачає наявність певних знань, педагогічних умінь i, звичайно, особистісних якостей. Наявність деяких особистісних характеристик дає можливість зменшити емоційне напруження, але повністю його позбутися неможливо.

Як наслідок професійного або емоційного вигорання може проявлятися у збільшенні кількості конфліктів, у байдужості до переживань іншої особистості, у втраті відчуття цінності життя, упевненості у власних силах і внутрішніх ресурсах.

Сьогодні можна констатувати три основні чинники, що впливають на синдром професійного вигорання:

- особистісний (якщо професійна діяльність сприймається як робота, що не є значущою для особистості, то зазначений синдром буде розвиватися швидше, бо невдоволеність професійним зростанням та установкою на підтримку асоціюється з розвитком «згорання» [9]);

- рольовий (наявність високого рівня відповідальності за покладені обов'язки є додатковим стресогенним чинником, що в результаті може спровокувати виникнення професійного вигорання);

- організаційний (вигорання пов’язане з тим, що професійна діяльність може бути неправильно організованою).

Уважаємо за необхідне на основі аналізу наукової літератури виокремити основні ознаки професійного вигорання як специфічного різновиду професійних деструкцій:

- пов'язане $з$ емоційним виснаженням особистості, під яким розуміється почуття емоційного спустошення й утоми, викликаної власне діяльністю;

- призводить до особливих форм деперсоналізації особистості, що проявляються в цинічному ставленні до діяльності та його суб'єктів;

- супроводжується редукцією й недооціненням фахівцем своїх професійних досягнень, що пов’язано 3 виникненням почуття некомпетентності у своїй професійній сфері, акцентуванням уваги на невдачах;

-є суто професійним явищем, тобто фіксується і проявляється у специфічних умовах професійної діяльності й розвитку;

- здійснює негативний вплив на всі сторони особистості та її поведінку, знижуючи, в кінцевому підсумку, ефективність професійної діяльності й задоволеність діяльністю;

- $є$ незворотнім - його неможливо повністю подолати в ході спеціальних форм впливу, можна лише загальмувати розвиток;

-є регресом професійного розвитку, оскільки зачіпає особистість загалом, руйнує іiі і здійснює негативний вплив на ефективність професійної діяльності; 
- не обмежений лише однією професійною сферою, а виявляється й у непрофесійному житті;

- усвідомлюється суб'єктом - виявляється у прагненні змінити роботу й у реалізації цього прагнення;

- здійснює суттєвий вплив на основні параметри професійної діяльності та професійної ідентичності;

- може з'явитися на початку професійного становлення як результат невідповідності між вимогами професії та домаганнями особистості [6].

На підставі виокремлення ознак професійного вигорання незаперечним є факт, що будь-якому негативному явищу легше запобігти, ніж подолати, тим паче з'ясовано, що професійне вигорання небезпечне наявністю широкого спектру симптомів невротичного та психосоматичного характеру й чинників, які вимагають диференційованих підходів до його психопрофілактики, психокорекції і психотерапії. Саме тому, на нашу думку, профілактика є одним із головних напрямів запобігання виникненню професійного вигорання.

Виходячи з вищезазначеного, зауважимо, що психологічна профілактика професійних деформацій базується на формуванні самоефективності, упевненості у власних силах, умінні правильно розрахувати свої ресурси та вчасно поповнити їх, навичок адекватної оцінки результатів власної діяльності (рефлексія).

Варто наголосити, що в процесі психопрофілактичної роботи з педагогами увагу треба акцентувати не на стані безпорадності та слабкості, а на розвитку аксіологічного й акмеологічного потенціалів і формування внутрішніх ресурсів адаптаційної енергії.

Зрозуміло, що сучасний педагог потребує не тільки психологічної допомоги, а й набуття конструктивних навичок саморегулювання суб'єктивної особистісної сфери.

Розглянемо деякі напрями профілактичної та психокорекційної роботи щодо запобігання професійному вигоранню та подолання професійного вигорання, серед яких доцільними можуть бути виявлення власного стилю реагування на стресову ситуацію, розширення поведінкового репертуару, відпрацювання навичок конструктивної взаємодії, робота щодо зміни установки, використання технік зняття напруження тощо.

Варто зауважити, що профілактичні та психокорекційні методики й технології повинні бути спрямовані на зняття дії стресора, зняття робочого напруження, підвищення професійної мотивації, вирівнювання балансу між затраченими зусиллями й результатом, який отримується.

Разом із тим однією з ефективних форм профілактики цього явища є тренінгові заняття й коучинг.

У межах означеної проблеми тренінг розглядаємо як запланований процес модифікації (зміни) ставлення, знання чи поведінкових навичок педагогів у стресовій ситуації через набуття навчального досвіду з метою досягнення ефективної суб'єкт-суб'єктної взаємодії та подальшого успішного здійснення професійної діяльності. Залежно від змісту проблеми варто використовувати індивідуальні та групові тренінги («Азбука спілкування», «Емоційна сфера», «Резонансне лідерство» тощо), у ході яких відпрацьовуються навички самодіагностики ознак професійного стресу та конструктивні шляхи його подолання. Під час тренінгів пропонуємо використовувати елементи арт-терапії: ізотерапію, казкотерапію, символдраму, музичну терапію та метафорично-асоціативні карти).

Окрім зазначених тренінгів, досить важливим для управління стресом є встановлення особистістю бар'єрів за допомогою спеціальних прийомів і методів на всіх фазах розгортання стресу 3 метою протидії йому, якими можна оволодіти під час асертивних тренінгів (асертивність - це здатність неагресивно вирішувати конфлікту ситуацію) [8].

Нині досить дієвим є метод коучингу, розглядаючи який науковці послуговувалися визначенням T. Gallwey та визначили його як неформальний метод консультативної підтримки, завдяки якій відбувається розкриття потенціалу особистості, з метою максимального підвищення його ефективності в процесі здійснення професійної діяльності.

Метод коучингу полягає в постановці та максимально швидкому досягненні мети шляхом мобілізації внутрішніх ресурсів, засвоєнні передових стратегій отримання результату. Разом із тим коучинг передбачає цілісний і багаторівневий підхід щодо вивільнення й розвитку прихованих ресурсів відповідно до потреб особистості.

Під час тренінгових занять і коучингів досить дієвими є саморегуляція, метод асоціювання, проведення психодрам. Розглянемо їх коротко.

Саморегуляція (підтримка емоційного та фізичного самопочуття, усвідомлене керування емоційним станом). Серед основних методів саморегуляції найбільш ефективними є такі:

- нервово-м'язова релаксація (виконання комплексу вправ, що складаються з чергування максимальних навантажень із розслабленням груп м'язів, завдяки чому знімається напруження з окремих частин тіла або всього тіла загалом, що викликає зменшення емоційного напруження);

- ідіомоторне тренування (як і попередня, ця техніка полягає в послідовному напруженні та розслабленні м'язів тіла, але вправи виконуються не реально, а подумки; цей метод оснований на реально доведених фактах (дослідження I. Павлова та «ефект Карпентера»), що підтверджують подібність стану м'язової тканини і процесі реального й уявного руху;

- сенсорна репродукція образів (розслаблення за допомогою уявлення образів, цілісних ситуацій, що асоціюються з відпочинком (прогулянка в лісі, відпочинок на морі тощо), зосереджуючись на правильному диханні та приємних відчуттях, які виникають у різних частинах тіла під дією уявної ситуації);

- аутогенне тренування (полягає в самонавіюванні та аутосугестії, що здійснюються через вербальні формулювання - самонакази; відбувається формування зв’язків між самонаказами та психофізіологічними процесами). 
Метод асоиіювання - комплекс вправ, які допомагають подолати дисоційовані стани шляхом занурення в стан асоціації [1].

Ще одним дієвим методом є психодрама, де широкого застосування набувають рольова гра й елементи імпровізації життєвих ситуацій, призначених для більш повного розкриття внутрішнього світу особистості [8].

Висновки. Отже, аналіз наукової психолого-педагогічної літератури та результатів численних досліджень синдрому професійного вигорання дає нам змогу узагальнити, що синдром професійного вигорання в педагогів як стан особистості, що виникає в процесі професійної діяльності, являє собою складний процес оріснтації особистості у власному інтраіндивідуальному просторі, що містить психоконституційні особливості й суб' єктивно-особистісне ставлення до професійної діяльності, яке виявляється в порушенні аутоідентифікації особистості, злитті із середовищними впливами на основі емоційної залученості.

Ефективність профілактики професійного вигорання в педагогів можлива за умови використання різноманітних психологічних методів і технологій, серед яких - тренінги, коучинги, вправи на саморегуляцію, метод асоціювання тощо.

\section{Використана література:}

1. Безносов С. П. Профессиональная деформация личности. Санкт-Петербург: Речь, 2004. 272 с.

2. Булатевич Н. М. Синдром емоційного вигоряння вчителя: автореф. дис. ... канд. психол. наук: 19.00 .04 «Медична психологія». Київ, 2004. 19 с.

3. Водопьянова Н. Е., Старченкова Н. Е. Синдром выгорания: диагностика и профилактика. Санкт-Петербург: Питер, 2005. $336 \mathrm{c.}$

4. Емоційне вигорання / упоряд. В. Дудяк. Київ: Главник, 2007. 127 с.

5. Жогно Ю. П. Психологічні особливості емоційного вигорання педагогів: дис. ... канд. психол. наук: 19.00.07. Одеса, 2009. 249 c.

6. Колтунович Т. А. Психологічні умови корекції професійного вигорання у вихователів дитячих навчальних закладів: дис. ... канд. психол. наук: 19.00.07. Івано-Франківськ, 2016. 352 с.

7. Курлянд 3. Н. Педагогические способности и профессиональная устойчивость. Одесса, 1992. 122 с.

8. Олійник I. В. Причини виникнення та профілактика синдрому професійного вигорання у педагогів. Вісник університету імені Альфреда Нобеля. Серія «Педагогіка і психологія. Педагогічні науки». 2017. № 1 (13). С. 118-125.

9. Орел В. Е. Синдром психического выгорания личности: монография. Ярославль: Институт психологии РАН, 2005.330 с.

10. Рогинская Т. И. Синдром выгорания в социальных профессиях. Психологический журнал. 2002. № 3. С. 85-95.

11. Рукавишников А. А. Опросник психического выгорания для учителей. Руководство. Ярославль, 2011. 14 с.

\section{References:}

1. Bezsonov, S. P. (2004). Professionalnaia deformatsiia lichnosti [Professional deformation of personality]. Sankt-Peterburh, Rech Publ., 272 p. (In Russian).

2. Bulatevich, N. M. (2004). Syndrom emotsiinihi vyhoriannia vchytelia. Avtoref. dys. kand. psykh. nauk [Syndrome of emotional burnout teacher. Abstr. cand. psych. sci. diss.]. Kyiv, 19 p. (In Ukrainian).

3. Vodopianova, N. E. \& Starchenkova, E. S. (2005). Sindrom vyhoraniia : diahnostika i profilaktika [Burnout syndrome : diagnosis and prevention]. Sankt-Peterburh, Piter Publ., 336 p. (In Russian).

4. In V. Dudiak (Ed.). (2007). Emotsiine vyhoriannia [Emotional burnout]. Kyiv, Hlavnik Publ., 127 p. (In Ukrainian).

5. Zhogno, Yu. P. (2009) Psyxologichni osoblyvosti emocijnogo vygorannya pedagogiv [Psychological peculiarities of emotional burnout of teachers]. Candidate's thesis. Odessa, 249 p. (In Ukrainian).

6. Koltunovich, T. A. (2016) Psyxologichni umovy korekciyi profesijnogo vygorannya u vyxovateliv dytyachyx navchalnyx zakladiv [Psychological conditions of correction of professional burnout at the teachers of children's educational institutions]. Candidate's thesis. Ivano-Frankivsk, 352 p. (In Ukrainian).

7. Kurliand, Z. N. (1992). Pedahohocheskie sposobnosti i professionalnaia ustoichivost [Pedagogical abilities and professional stability]. Odessa, 122 p. (In Russian).

8. Oliynyk, I. V. (2017) Pryčyny vynyknennja ta profilaktyka syndromu profesijnoho vyhorannja u pedahohiv [Causes and prevention of professional burnout syndrome in teachers]. Bulletin of the University named after Alfred Nobel. Series «Pedagogy and Psychology». Pedagogical sciences. No. 1 (13), pp. 118-125 (In Ukrainian).

9. Orel, V. E. (2005). Sindrom psikhicheskoho vyhoraniia lichnosti [Syndrome of mental burnout of a person]. Yaroslavl, Institut psikholohii RAN Publ., 330 p. (In Russian).

10. Rohinskaia, T. I. (2002). Sindrom vyhoraniia v sotsialnykh profesiiakh [Burnout syndrome in social occupations]. Psikholohichiskii zhurnal [Psychological journal], no. 3, pp. 85-95 (In Russian).

11. Rukavishnikov, A. A. (2011). Oprosnik psikhicheskoho vyhoraniia dlia uchitelei [Mental burnout questionnaire for teachers]. Yaroslavl, 14 p. (In Russian).

\section{Pidlypniak I. Yu., Duka T. M. Professional burnout by teachers: prevention and overcoming}

The article is devoted to the results of the comparative analysis of the terminology apparatus, which is used to refer to the phenomenon of "professional burnout». The factors, causes and symptoms of occurrence of this phenomenon are determined. The basic directions of prevention of professional burnout of specialists of the pedagogical sphere are outlined. The emphasis is on the need to study the use of preventive methods and technologies for the prevention of professional burnout.

Modern scholars have found that the representatives of professions related to interaction with people, in particular, teachers in connection with the great emotional tension, non-standard pedagogical situations, responsibility and complexity are prone to the development of a syndrome of "professional burnout». A teacher as a subject of an educational process exercises influence on a person through the prism of the formation of his own actual, holistic sphere precisely because if he is inclined to emotional burnout, he needs help. 
The syndrome of «burnout» is considered by psychologists as one of the manifestations of stress that a person encounters in his or her professional activity. This term is a common name for the consequences of long working stress and certain types of professional crisis. In the emergence and development of signs of emotional burnout, it is necessary to pay attention to the improvement of working conditions, the nature of interactions in the team, personality reactions and morbidity. A significant role in the fight against the emotional burnout syndrome is given to the person himself. In order to prevent a syndrome of «professional burnout», you must adhere to the recommended principles of your own behavior and professional activity: planning and standardizing pedagogical activities, compulsory rest, entertainment and relaxed and enjoyable physical activity, psychological discharges, avoidance of unhealthy competition and patience.

Key words: teacher, professional burnout, emotional burnout, prevention of occupational burnout syndrome.

УДК 37.091.12:005.745:[37.035:343.811-053.6](477)»18/19»

DOI https://doi.org/10.31392/2311-5491/2019-69.42

Пліско Є. Ю.

\section{ЩОДО ОРГАНІЗАЦІЇ З’ЇЗДІВ ПРЕДСТАВНИКІВ ВИПРАВНИХ ЗАКЛАДІВ ДЛЯ НЕПОВНОЛІТНІХ НАПРИКІНЦІ ХІХ - ПОЧАТКУ ХХ стоЛіТтЯ}

У статті зроблено спробу дослідити питання організації різноманітних зустрічей, конференцій та інших з 'їдів представників освіти й громадськості кіния XIX - початку XX cm., на яких вирішувалися проблеми піклування знедолених дітей, прилаштування бездоглядних і безпритульних, виховання неповнолітніх правопорушників та інших морально знівечених дітей. На прикладі опису організаиї з 'іздів представників виправних установ для неповнолітніх зазначено участь украӥнських діячів освіти (Б. Грінченко, М. Драгоманов, М. Лубенеиь, Д. Пальчиков, І. Стешенко, М. Сумиов) у різноманітних суспільних зустрічах, конференціях, присвячених освітнім питанням дітей і молоді того часу. Самі з'ізди представників виправних закладів для неповнолітніх відбивали результати пенітенціарної педагогічної практики, порушували питання соиіального захисту дитинства, зокрема питання організаційного характеру - про порядок розміщення, утримання й подальшого влаштування неповнолітніх. Аналізувався здобутий педагогічний досвід роботи з організаиії медико-педагогічного нагляду, проведення патронату тощяо.

Коротко відбито освітньо-педагогічні нароби деяких представників громадськості того часу (К. Рукавишникова, М. Таганцева, О. Фідлера), які найбільш чинно визначили процес розвитку вітчизняної теорії і практики соціального виховання знедолених дітей в означений час дослідження, основні пріоритети вітчизняної педагогіки, ії кониепиії та принииии. Поряд із теоретичними напрацюваннями йшов пошук ефективних засобів практичного врегулювання знедоленого дитинства: представниками спільноти організовувалися иентри опіки; створювалися заклади позашкільної освіти для дітей; уносилися теоретичні інноваиії в галузі виховання тощзо.

Засвідчення утворення товариств, спілок освітніх закладів суспільного й приватного піклування є для нас доказом, щз в краӥні в означений історичний час виокремився соціально-педагогічний напрям виховної роботи з неповнолітніми, метою якого було надати соияіальний захист і підтримку знедоленого дитинства.

Ключові слова: сочіально-педагогічне виховання, з їзди представників виправних закладів для неповнолітніх, безпритульні, бездоглядні, неповнолітні правопорушники.

Звернення до педагогічного досвіду минулого допоможе зрозуміти концепції вітчизняних традицій в освітньому полі країни, відстежити активність громадськості і становлення державного пенітенціарного інституту. Перші спроби ініціативної участі суспільства в освітньо-виховному процесі країни відстежуються наприкінці XIX - на початку XX ст., говорять нам про активізацію суспільної і приватної ініціативи в організації та розвитку різноманітних зустрічей, конференцій, різноманітних з'їздів, представників освіти й громадськості, на яких порушувалося питання соціального виховання знедолених дітей (сиріт, безпритульних, бездоглядних та ін.). Зазначення факту організації громадськістю державного соціального інституту з вирішення цієї проблеми говорить нам про утворення колегіального органу громадської самодіяльності, історичне висвітлення якого допоможе нам детальніше побачити й зрозуміти становлення системи соціального виховання країни в минулому.

Мета статті - на прикладі організації з'їздів представників виправних закладів для неповнолітніх (кінець XIX - початок XX ст.) визначити феномен активності громадськості в організації процесу соціального виховання знедолених дітей (сиріт, бездоглядних, безпритульних, неповнолітніх правопорушників).

Розгортання проблеми «дитяча знедоленість» на межі XIX - XX ст. призвело до того, що науковці-теоретики, діячі науки та інші представники спільноти вважали за необхідне налаштування державного соціального інституту з питань організації виховання, патронату й піклування над неповнолітніми. А через збільшення публічного інтересу до справи виправлення противоправної поведінки малолітніх зусиллями громадської ініціативи наприкінці XIX ст. у країні було сформовано організаційні засади соціально-педагогічної роботи з неповнолітніми правопорушниками. Популярність отримали з'їзди представників виправних закладів для неповнолітніх, на яких порушували питання виховання знедолених дітей.

Перший з’їзд представників виправних закладів відбувся в Москві (1881 р.) у приміщенні Рукавишниковського виправного притулку. У з’їзді брали участь міський голова С. Третьяков, представники від 